\title{
Nise \\ First report of Phytophthora nicotianae causing wilting and desiccation on Buxus sempervirens in Italy
}

L. Luongo, M. Galli, A. Haegi, P. Proietti and A. Belisario*

\author{
Agricultural Research Council-Plant Pathology Research Centre (CRA-PAV), Via C. G. Bertero 22, 00156 Roma, Italy \\ *E-mail: alessandra.belisario@entecra.it
}

Received: 27 Jun 2013. Published: 20 Sep 2013. Keywords: boxwood, oomycetes, nursery disease

Boxwood (Buxus spp.) is one of the oldest genus of ornamental garden plants in Europe and is mainly used for hedging and topiary work (Batdorf, 1997). The most commonly planted species is Buxus sempervirens. In late September 2012, collar and root rot associated with severe wilting and desiccation of foliage were observed on boxwood potted plants grown in commercial nurseries in central Italy. Of two hundred boxwood plants observed, more than 50\% showed these symptoms, and most had the canopy with evident straw colour and diffused desiccation resulting in $20 \%$ mortality. Leaves at first appeared light green (Fig. 1), then turned yellow to straw coloured (Fig. 2). Foliar symptoms were initially restricted to a few branches and then extended to most of the canopy. A Phytophthora species was consistently recovered by plating small pieces of stem and root tissues cut from the margin of lesions on P5ARPH selective medium (Jeffers \& Martin, 1986). A similar species was recovered from soil samples baited with azalea and camellia leaves. Isolates were identified as $P$. nicotianae based on morphological characteristics and DNA analysis. Colonies were arachnoid on potato dextrose agar (PDA), and produced uni-and bi-papillate, prevalently non-caducous, ovoid, pyriform to spherical sporangia (Fig. 3). The average sporangium size was $46 \times 40 \mu \mathrm{m}$ with a length/width ratio of 1.15 Chlamydospores were both terminal and intercalary. All isolates were mating type A2. The identity was confirmed by internal transcribed spacer (ITS) sequence comparison, indicating $100 \%$ homology with sequences available in GenBank (e.g. Accession No. JF792541), and 99\% homology with cytochrome c oxidase subunit II (Cox II) (AY129216; Martin \& Tooley, 2003). The sequences of one isolate AB205 were deposited in the European Nucleotide Archive (ENA) with Accession Nos. HG007960 and HG007961 for ITS and Cox II, respectively.

Pathogenicity tests were conducted in the greenhouse with the strain AB205 on 10 two-year-old shoots cut from boxwood plants with two inoculation points each. Mycelial plugs (5 $\mathrm{mm}$ diameter) cut from the margins of actively growing 15-day-old cultures on PDA were inserted through the epidermis to the phloem. Controls were treated as described above except for inoculation with sterile PDA plugs. After inoculation, shoots were incubated in test tubes with sterile water for one week in the dark at $22 \pm 2^{\circ} \mathrm{C}$. Lesions were evident at the inoculation points. $P$. nicotianae was consistently re-isolated from the margin of symptomatic tissues. Controls remained symptomless. Decline and root rot of boxwood plants has been reported to be caused by $P$. citricola in Poland, $P$. nicotianae var. parasitica in Virginia, and $P$. citrophthora in North Carolina. To our knowledge this is the first report of $P$. nicotianae on Buxus sempervirens in Italy where $P$. citrophthora has been already reported in Buxus rotundifolia by Vettraino et al. (2010).

\section{Acknowledgements}

The authors wish to thank Dr. Moreno Moraldi and Dr. Stefano Berti for their scientific and technical support. The work was financially supported by the FLORSUBVIVO project granted by the National Ministry of Agriculture (MiPAAF)

\section{References}

Batdorf L, 1997. Boxwood handbook: a practical guide to knowing and growing boxwood. 3rd edition. Boyce, VA, USA: The American Boxwood Society.

Jeffers SN, Martin SB, 1986. Comparison of two media selective for Phytophthora and Pythium species. Plant Disease 70, 1038-1043. [http://dx.doi.org/10.1094/PD-70-1038]

Martin FN, Tooley PW, 2003. Phylogenetic relationships among Phytophthora species inferred from sequence analysis of mitochondrially encoded cytochrome oxidase I and II genes. Mycologia 95, 269-284. [http://dx.doi.org/10.2307/3762038]

Vettraino AM, Franceschini S, Vannini A, 2010. First Report of Buxus rotundifolia root and collar rot caused by Phytophthora citrophthora in Italy. Plant Disease 94, 272. [http://dx.doi.org/10.1094/PDIS-94-2-0272A]

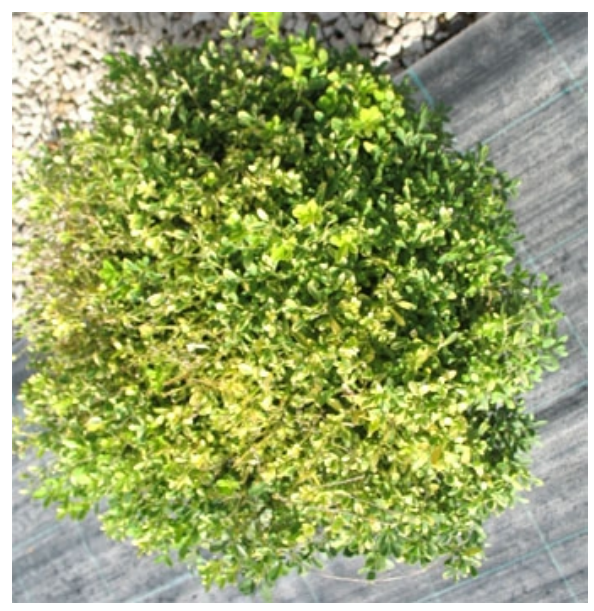

Figure 1

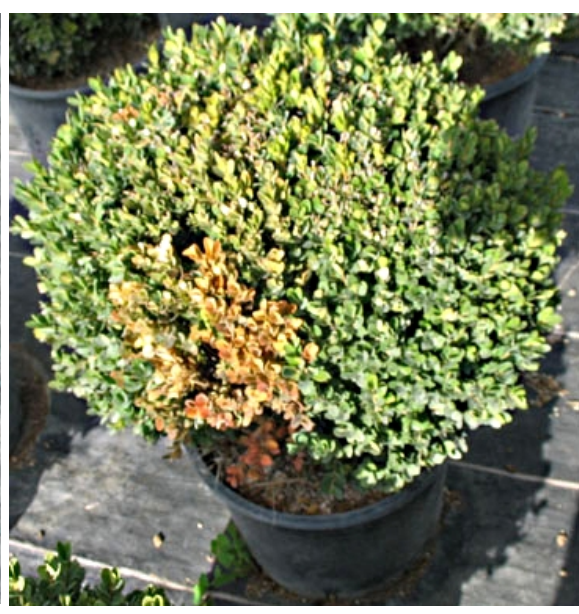

Figure 2

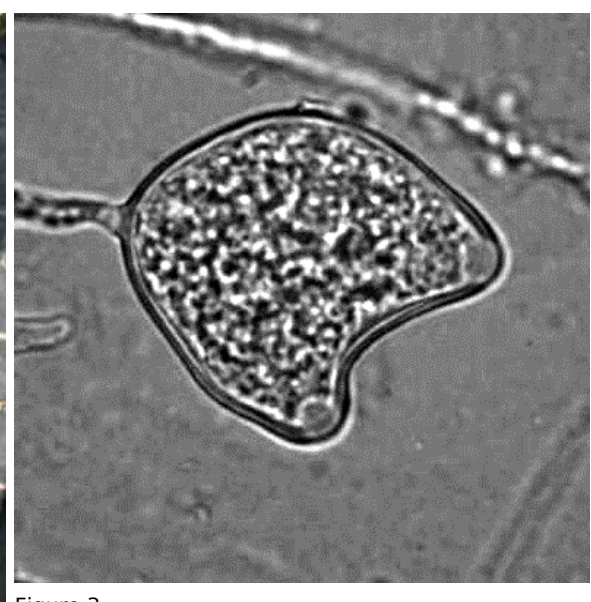

Figure 3

To cite this report: Luongo L, Galli M, Haegi A, Proietti P, Belisario A, 2013. First report of Phytophthora nicotianae causing wilting and desiccation on Buxus sempervirens in Italy. New Disease Reports 28, 5. [http://dx.doi.org/10.5197/j.2044-0588.2013.028.005]

(c) 2013 The Authors

This report was published on-line at www.ndrs.org.uk where high quality versions of the figures can be found. 